\title{
Characteristics of Patients with End-Stage Renal Disease at Dialysis Unit Dr. Soetomo General Hospital Surabaya
}

\author{
Leny Silviana Farida ${ }^{1}$, Mochammad Thaha ${ }^{2 *}$, Dwi Susanti ${ }^{3}$ \\ ${ }^{1}$ Faculty of Medicine, Universitas Airlangga, Surabaya, Indonesia \\ ${ }^{2}$ Department of Internal Medicine, Faculty of Medicine, Universitas Airlangga - Dr. Soetomo General Hospital, Surabaya, \\ Indonesia \\ ${ }^{3}$ Department of Public Health and Preventive Medicine, Faculty of Medicine, Universitas Airlangga, Surabaya, Indonesia
}

\section{A R T I C L E I N F O}

\section{Article history:}

Received 15 Augusrt 2018

Received in revised form 14

September 2018

Accepted 25 September 2018

Available online 30 November

2018

Keywords:

ESRD,

Hypertension,

Diabetes Mellitus,

Smoke.

*) Corresponding author:

mochthaha@yahoo.com

\begin{abstract}
A B S T R A C T
Introduction: The prevalence of end stage renal disease (ESRD) in Indonesia is increasing over the last decade. Most cases highest risk factor are Diabetes Mellitus (DM) and hypertension. Other factors such as lifestyle and environment; both play important role in the development of ESRD. Thus, this study aimed to assess the characteristic of patient with ESRD.

Methods: This was a descriptive study acquired by interviewing 126 patients with ESRD who have been undergoing continuous hemodialysis in dialysis unit of Dr. Soetomo General Hospital Surabaya for at least 3 months using questionnaire about history of disease, smoking habit, sex, and ethnic group. All data was analyzed using frequency distribution and percentage.

Results: Form 126 patients, consist of 61 male patients (48.4\%) and 65 female (51.6\%). 45 patients $(35.7 \%)$ have the history of DM; 98 patients $(77.0 \%)$ of hypertension; 35 patients $(27.8 \%)$ of hypertension and DM; and 19 patients $(15.1 \%)$ have none of them. Later age adult (36-45 years old) has the largest group proportion (34.13\%). There are 36 patients $(28 \%)$ who are smokers. 108 patients $(85.7 \%)$ are Javanese.

Conclusion: Most of the patients have hypertension as the risk factor and in later age group adult. Characteristics of patient with ESRD is caused by multifactorial factors. Therefore, patient with high risk factor should be aware and do preventive steps in progressiveness of the disease.
\end{abstract}

\section{Introduction}

End Stage Renal Dosease (ESRD) has become the main concern in medical world due to its high prevalence; increasing cardiovascular risk and mortality rate. The number of ESRD patients has been escalating globally. In USA, the prevalence also steadily increasing. ${ }^{1}$ Meanwhile, the number of new patients undergoing hemodialysis in Indonesia has increased threefold in 2011 compare to the number in $2007 .{ }^{2}$ Based on the data obtained at the dialysis unit of Dr. Soetomo Hospital Surabaya, the number of ESRD patients routinely treated twice a week has increased for these last three years; 245 patients in 2003, 255 patients in 2014, and 303 patients in 2015.

Some of the factors that initiated the occurrence of ESRD are hypertension, Diabetes Mellitus (DM), kidney inflammation, kidney stones and infection, and polycystic kidney disease. ${ }^{3}$ Kidney foundation in 2003 explained several factors that could cause ESRD based on the disease etiology, divided into diabetic, nondiabetic, and transplantation. ${ }^{4}$ Hypertension is one of non-diabetic disease cause of ESRD. ${ }^{5}$ Harmful substances in cigarettes can instigate the rise of cell proliferation and fibronectin mass; which further could destroy kidney's structure. ${ }^{6}$ Diabetes mellitus (DM)

Biomolecular and Health Science Journal

Available at https://e-journal.unair.ac.id/BHSJ ; DOI: 10.20473/bhsj.v1i2.9400 
patients with smoking habit will experience a more rapid rate of microalbuminuria in diabetic nephropathy. ${ }^{7}$ Initial age diagnosed and sexes are the internal factors in

disease progressivity. Patients' race is a genetic factor that affect the ESRD. ${ }^{8}$ Asian and Indian diabetes mellitus patients tend to suffer from microalbuminuria. ${ }^{7}$

Kidney Disease Improving Global Outcomes (KDIGO) in 2012 proposed that dialysis should be initiated if there are one or more conditions, namely signs or symptoms that support kidney failure (serositis, acid-base and electrolyte abnormalities, pruritus), no volume status and blood pressure can be controlled, progressive worsening of nutritional status, and the presence of cognitive impairment. Dialysis is performed in patients with ESRD who lose $85 \%$ to $95 \%$ of normal kidney function and LFG values $<15 \mathrm{~mL} / \mathrm{min} / 1.73$ $\mathrm{m}^{2}{ }^{2}$ In addition, several factors that causing ESRD has became main concern in medical field. Therefore, this study aims to know the ESRD patients' characteristics at the dialysis unit of Dr. Soetomo General Hospital Surabaya.

\section{Methods}

This was a descriptive study using primary data that obtained by interviewing respondents at the dialysis unit of Dr. Soetomo Hospital Surabaya from March $9^{\text {th }} 2015$ to April $23^{\text {rd }}$ 2015. The inclusion criterias were all respondents who have undergone continuous hemodialysis; fulfill all criteria of ESRD according to NKF-K/DOQI (2012); and are willing to be a respondent, while the exclusion criteria were patients with congenital abnormalities of the kidney. The data observed in this study were ESRD patients with past illnesses (hypertension, diabetes mellitus, both diseases, or no history of both diseases), smoking habits, age, gender, and races. The datas were analyzed and presented in percentage and frequency distribution table.

\section{Results}

There were 126 respondents fulfilled criteria (table 1). The youngest patient was 13 years old; while the oldest one was 72 years old. The average age of the patients undergoing hemodialysis was 47.5 years old. The sex proportion mostly were male $(48,4 \%)$ compared to female $(34,13 \%)$. Based on patient comorbid illness, there were 45 patients $(35.7 \%)$ with DM; 97 patients (77.0\%) with hypertension; 35 patients (27.8\%) with both DM and hypertension; and lastly, 19 patients (15.1\%) without DM and hypertension.

There are 36 patients with smoking history, in which moderate smoker 17 patients $(47.2 \%)$ who consumed 1020 cigarettes in a day and heavy smoker 13 patients $(36.1 \%)$ who consumed more than 20 cigarettes per day. Moreover patients $(34.13 \%)$ were diagnosed at later age adult (36-45 years old). We found that most of the patients are Javanese $(85.7 \%)$.
Table 1. CKD Stage 5 Patients' Characteristics

\begin{tabular}{|c|c|}
\hline Characteristics & $\begin{array}{l}\text { Number } \\
\mathrm{n}=126\end{array}$ \\
\hline \multicolumn{2}{|l|}{ History of Present Illness (n (\%)) } \\
\hline DM & $10(7.9)$ \\
\hline Hypertension & $62(49.2)$ \\
\hline DM and Hypertension & $35(27.8)$ \\
\hline Without DM and Hypertension & $19(15.1)$ \\
\hline \multicolumn{2}{|l|}{ Smoking habit (n (\%)) } \\
\hline Yes & $36(28.6)$ \\
\hline Light (<10 cigarettes/day) & $6(1.7)$ \\
\hline Moderate (10-20 cigarettes/day) & $17(47.2)$ \\
\hline Heavy (>20 cigarettes/day) & $13(36.1)$ \\
\hline No & $90(71.4)$ \\
\hline \multicolumn{2}{|l|}{$\begin{array}{l}\text { Initial age when they were diagnosed with } \\
\text { stage five CKD }(\mathrm{n}(\%))\end{array}$} \\
\hline Early Adolescence (12-16years old) & $3(2.4)$ \\
\hline Late Adolescence (17-25years old) & $5(4.0)$ \\
\hline Early Adult (26-35years old) & $13(10.3)$ \\
\hline Late Adult (36-45years old) & $43(34.1)$ \\
\hline Early Elderly (46-55 years old) & $41(32.5)$ \\
\hline Late Elderly (56-65years old) & $20(16.9)$ \\
\hline Seniors $(>65$ years old $)$ & $1(0.8)$ \\
\hline \multicolumn{2}{|l|}{$\operatorname{Sex}(\mathrm{n}(\%))$} \\
\hline Male & $61(48.4)$ \\
\hline Female & $65(51.6)$ \\
\hline \multicolumn{2}{|l|}{ Race (n (\%)) } \\
\hline Javanese & $108(85.7)$ \\
\hline Maduranese & $10(7.9)$ \\
\hline Malay & $2(1.6)$ \\
\hline Indonesian Born Chinese & $5(4.0)$ \\
\hline Indonesian Born Arabian & $1(0.8)$ \\
\hline
\end{tabular}

\section{Discussion}

ESRD is a condition of renal damage that lasts in 3 months or more due to structural or functional abnormality of the kidney; with or without the deteriorating of Glomerular Filtration Rate (GFR); or if the GFR rate is less than $60 \mathrm{~mL} /$ minutes $/ 1.73 \mathrm{~m}^{2}$ for more than 3 months, with or without renal damage. ${ }^{4}$ Decrease of GFR to less than $15 \mathrm{~mL} / \mathrm{minute} / 1.73 \mathrm{~m}^{2}$ or patients that have been treated with dialysis are also classified in ESRD. The decreased kidney function is progressive and irreversible. The cause of ESRD are classified into three main groups: diabetic kidney disease, non-diabetic kidney disease (one of them is hypertension), and transplantation related disease. ${ }^{4}$ In this study, most patients diagnosed with ESRD also suffer from hypertension $(77.0 \%)$. This result in line with previous study that showed that $68.8 \%$ ESRD patients in Yogyakarta and 68,9\% ESRD patients in Palembang also suffered from hypertension. ${ }^{6}$ Hypertension may trigger the increase of intraglomerular hyperfiltration and further escalate the kidney's structural and functional damage. Microvascular disruption are triggered by the changing of afferent arterioles resistance and the narrowing of 
efferent arteriole. This condition could cause glomerular ischemic and activates inflammatory response. Later, it will result in apoptosis, increase the production of matrix, deposit on the glomerular microvascular, and cause nephrosclerosis. ${ }^{9}$

Beside hypertension, DM is also commonly suffered by ESRD patients, this study result found 45 patients $(35.7 \%)$ has it, same with Palembang result. ${ }^{9}$ Glucotoxicity in diabetic patients creates two main pathways to form diabetic nephropathy (ND): the hemodynamic and metabolic pathways. In hyperglycemia metabolic pathway (increased glucose level in blood), it reacts non-enzymatically with free amino acids and produce Advance Glycosylation Endproducts (AGE's). The increased of AGEs will damage glomerulus as seen from histopathology study will show the glomerular basement membrane thickening due to hyperfiltration and hyperperfusion; as well as the expansion of mesangial and vascular cells in the kidney. While in the hemodynamic pathway, the systemic hemodynamic and kidney disturbance cause abnormal endothelial cells of the blood vessels. Hemodynamic disturbance will result in vasoactive hormone elevation, angiotensin hormone II. $^{7}$ Based on the data from NKUDIC (2014), several diseases that cause ESRD in United States were hypertension (28\%); diabetes mellitus $(44 \%)$; urology related disease $(1 \%)$; glomerulonephritis (7\%); renal cysts $(2 \%)$; and other causes $(18 \%){ }^{3}$

In this study, patients who smoking habits are categorized into moderate and heavy smokers. High percentage of smoker was also found in Yogyakarta. ${ }^{6} \mathrm{~A}$ study conducted in 2015 stated that the incidence rate for patients at Wates General Hospital, Kulon Progo with smoking habit is twice higher than those without. ${ }^{10}$ Cigarette contain toxic substances that can cause damage to the endothelium, including the kidney's vascular endothelium. Nicotine triggers human cells to proliferate and increase the fibronectin mass until 50\%. ${ }^{11}$ The accumulation of cadmium $(\mathrm{Cd})$ contained in a cigarette can cause renal cortex damage and form scar tissue. ${ }^{10}$

Most patients have diagnosed with ESRD in their productive ages. The average initial age diagnosed with ESRD was 47.5 years old. In addition, there are approximately $76.2 \%$ patients undergo hemodialysis treatment in Dr. Soetomo General Hospital Surabaya twice a week; $31 \%$ of them are not from Surabaya and $74.6 \%$ are unemployed. This information may become a concern as it is related with patients' productivity that lowering quality of life while undergoing hemodialysis treatment. This result is in line previous study that confirmed $31,7 \%$ of ESRD patients at Al-Ihsan Hospital Bandung are at their productive ages (45-54 years old). ${ }^{12}$ Age itself significantly influences the progressivity of kidney damage. After someone reaches 30 years old, atrophy will occur and the renal cortical thickness will be reduced approximately $20 \%$ in the each following decade. It will also accelerate the progressivity of glomerular membrane thickened, the expansion of glomerular mesangium, and the extracellular matrix protein deposits that caused glomerulosclerosis. ${ }^{9}$

In this study, 61 patients $(48.4 \%)$ are male and 65 patients $(52.6 \%)$ were female, in accordance with other studies findings that showed female patients number were significantly higher. ${ }^{9}{ }^{12}$ Women over 60 years old, the majority of whom are presumably post-menopausal, has higher odds of advanced diabetic kidney disease compared to men of the same age. ${ }^{13}$ Poor glycemic control is the main risk factor for female patients and significantly associated with renal progression. ${ }^{14}$

Patients who undergo hemodialysis at Dr. Soetomo Hospital Surabaya are mostly Javanese $(85.7 \%)$. It is due to Dr. Soetomo's Hospital Surabaya as the reference hospital in East Java province which is heavily populated by Javanese. Race identity itself may act as the trigger for ESRD. Based on study in 2010 on multiethnic Singaporean, it was obtained that most patients were Malay $(22.8 \%)$, followed by Indiana $(21.9 \%)$ and Chinese (13.8\%). ${ }^{10}$ Furthermore, Bennet and Aditya (2015) confirmed that Asian and Indian diabetes mellitus patients are more likely having microalbuminuria. ${ }^{7}$ Microalbuminuria is defined as the urinary excretion of $30-300 \mathrm{mg} / \mathrm{d}$ in a timed urine collection in adults. It is a manifestation of a diffuse endothelial (microvascular) injury and thereby collateral kidney damage. Microalbuminuria may reduce eGFR and greatly magnified the effect of it on risk for ESRD. ${ }^{15}$

\section{Conclusion}

The ESRD patients at dialysis unit of Dr. Soetomo general hospital Surabaya are dominated by female, with hypertension, and moderate smokers as the risk factor. Most of respondents have diagnosed in their productive year which lowering the productivity and patients are mainly Javanese, but the influence of ethnic ESRD is not clearly understood.

\section{Conflict of Interest}

The author stated there is no conflict of interest.

\section{References}

1. NKUDIC. Kidney Disease Statistics for The United State. NIH Publication. 2012; 12.

2. PERNEFRI. Annual Report of Indonesian Renal Registry. In: 4, (ed.). Report of Indonesian Renal Registry. 2011.

3. NIDDK. Diabetic Kidney Disease. Washington: NIH, 2014.

4. Kidney Foundation N. K/DOQI Clinical Practice Guidelines for Bone Metabolism and Disease in Chronic Kidney Disease. 2003, p.S1-S201.

5. Beevers G, Lip GY and O'Brien E. ABC of Hypertension. Blood Pressure Measurement. Part I-sphygmomanometry: Factors Common to All Techniques. Bmj. 2001; 322: 981-5.

6. Hidayati HK, Suhardi, Titiek. Hubungan antara Hipertensi, Merokok dan Minuman Suplemen Energi dan Kejadian Penyakit Ginjal Kronik. 2012; 24.

7. Bennett K and Aditya B. An Overview of Diabetic Nephropath: Epidemiology, Pathophysiology, and Treatment. Journal of Diabetic Nursing. 2015; 18: 61-7.

8. Sabanayagam C, Lim SC, Wong TY, Lee J, Shankar A and Tai ES. Ethnic Disparities in Prevalence and Impact of Risk Factors of 
Chronic Kidney Disease. C. Sabanayagam et al. Nephrology Dialysis Transplantation. 2010; 25: 2564-70.

9. Tjekyan R. Prevalensi dan Faktor Risiko Penyakit Ginjal Kronik di RSUP Dr. Mohammad Hoesin Palembang Tahun 2012. Majalah Kedokteran Sriwijaya. 2012: 46.

10. Pranandari R and Supadmi W. Faktor Risiko Gagal Ginjal Kronik di Instalasi Hemodialisis RSUD Wates Kulon Progo. Majalah Farmaseutik. 201511.

11. Jain G and Jaimes EA. Nicotine Signaling and Progression of Chronic Kidney Disease in Smokers. Biochemical Pharmacology. 2013; 86: 1215-23.

12. Putri. Karakterisitk Pasien Gagal Ginjal Kronis yang Dilakukan Hemodualisis di RSUD Al-Ihsan Tahun 2014. Prosiding Pendidikan Dokter. 2014; 2.

13. Yu MK, Lyles CR, Bent-Shaw LA, Young BA and the Pathways A. Risk Factor, Age and Sex Differences in Chronic Kidney Disease Prevalence in A Diabetic Cohort: The Pathways Study. American Journal of Nephrology. 2012; 36: 245-51.

14. Chang P-Y, Chien L-N, Lin Y-F, Wu M-S, Chiu W-T and Chiou H-Y. Risk Factors of Gender for Renal Progression in Patients with Early Chronic Kidney Disease. Medicine. 2016; 95: e4203.

15. Glassock RJ. Is the Presence of Microalbuminuria a Relevant Marker of Kidney Disease? Current Hypertension Reports. 2010; 12: $364-8$. 